\title{
An outbreak of food-borne botulism in Scotland, United Kingdom, November 2011
}

L M Browning ${ }^{1}$, H Prempeh², C Little ${ }^{3}$, C Houston ${ }^{4}$, K Grant ${ }^{5}$, J M Cowden (john.cowden@nhs.net) ${ }^{1}$, on behalf of the United Kingdom Botulism Incident Management Team ${ }^{6}$

1. Health Protection Scotland, National Health Service National Services Scotland, Glasgow, United Kingdom

2. National Health Service Forth Valley, Stirling, United Kingdom

3. Health Protection Services - Colindale, Health Protection Agency, London, United Kingdom

4. Food Standards Agency, London, United Kingdom

5. Foodborne Pathogens Reference Unit, Health Protection Agency, Centre for Infections, London, United Kingdom

6. Representatives from Health Protection Scotland, Health Protection Agency, Forth Valley NHS Board, Stirling Council, Greater Glasgow and Clyde National Health Service Board, the Scottish Government

Citation style for this article:

Browning LM, Prempeh H, Little C, Houston C, Grant K, Cowden JM, on behalf of the United Kingdom Botulism Incident Management Team. An outbreak of foodborne botulism in Scotland, United Kingdom, November 2011.

Euro Surveill. 2011;16(49):pii=20036. Available online: http://www.eurosurveillance.org/ViewArticle.aspx?Articleld=20036

Article published on 8 December 2011

An investigation is currently underway to explain an outbreak of food-borne botulism in Scotland. Three children in the same family were confirmed as having botulism following consumption of a meal made with a jar of korma sauce. Residual sauce from the jar, the jar lid and a remnant of the meal, all tested positive for Clostridium botulinum type A toxin. The children are recovering, although two remain ventilated and in intensive care unit.

\section{Case description}

In early November 2011, on two consecutive days, two siblings were admitted to hospital in Scotland with botulism diagnosed on the basis of clinical symptoms. Both children had initial symptoms of blurred vision followed by difficulty in swallowing and a descending paralysis. Both children were ventilated and trivalent botulinum antitoxin was administered, after which their condition remained stable.

Six days after the first child was admitted to hospital, a third younger sibling became unwell and deteriorated over the course of the next day. A day later, the child began to choke whilst trying to swallow liquids. This sibling was also hospitalised with a suspected diagnosis of botulism. Trivalent antitoxin was administered, and the child was discharged from hospital six days after admission.

\section{Epidemiological investigation}

The local Public Health team, supported by the Local Authority, Food Standards Agency, Health Protection Scotland and Health Protection Agency (HPA) carried out an intensive investigation including a comprehensive food history for the three days prior to symptom onset (with particular emphasis on the previous 36 hours). Korma sauce, a mild curry sauce with a blend of cream, coconut and almonds, was one of the many foods reported in the food history. The korma sauce that had been served during a family meal two days before the first sibling was admitted to hospital, had been eaten by the two elder siblings, and tasted by the third sibling and the father (but not the mother). The sauce in question was a commercially prepared food product distributed in the United Kingdom (UK) and Ireland.

\section{Microbiological and \\ toxicological investigation}

Clinical specimens (serum, rectal washouts and gastric aspirates) and environmental samples taken from the children's home were examined for Clostridium botulinum and botulinum neurotoxin by the Foodborne Pathogens Reference Unit, HPA. Environmental samples from the family's rubbish bins and recycling boxes were taken. These included the remains of food items, used jars and containers with remnants of a number of foods, suspected on the basis of previous incidents and biological plausibility.

Botulinum neurotoxin was detected in the two older siblings' sera by a neutralisation mouse bioassay (MBA) [1] four days after the first sibling was hospitalised. C. botulinum type A was detected and subsequently isolated from their rectal washouts confirming a diagnosis of botulism. A day later, $C$. botulinum type A toxin was detected by MBA in residual sauce present in the empty used glass jar from a recycling box, its lid from a rubbish bin, and remnant of a chicken and korma sauce meal (which had been spat out by one of the two siblings and wrapped in tissue). Seven days after the third younger sibling was admitted to hospital, $C$. botulinum type A was detected in the latter's stool specimen by MBA and subsequently isolated, confirming a diagnosis of botulism. 
All other items from the rubbish bin and recycling box that were tested were negative for botulinum neurotoxin.

\section{Control measures}

The implicated batch of korma sauce which had been distributed across the UK and Ireland was withdrawn from sale [2]. Consumers were warned not to eat sauce from this batch. Warnings were also issued to the public and to medical professionals about the signs and symptoms of botulism [3]. Similar warnings were issued throughout the rest of the UK and Europe, via the Early Warning Response System (EWRS) and the Rapid Alert System for Food and Feed (RASFF). Emergency procedures were put in place to ensure that clinicians could obtain botulinum antitoxin if required.

Exhaustive investigations of production and distribution of the korma sauce are continuing, but at present there is no indication of how the jar became contaminated, nor any evidence that any other jars of korma sauce from the same batch were contaminated. This product was not available on retail sale outside the UK and Ireland.

\section{Conclusions}

Food-borne botulism caused by $C$. botulinum is very rare in the UK. Since 1922 there have only been 17 recorded incidents in the UK, the largest of which was a general outbreak in 1989 affecting 27 people, caused by a contaminated batch of commercially produced hazelnut yoghurt [4]. Between 1998 and 2006, seven incidents of food-borne botulism, (one household cluster of two cases, and six apparently sporadic cases) were reported in the UK, with home-preserved food sourced outside the UK responsible for most (4/7 incidents) (Kathie Grant, personal communication, November 2011) [4].

In early November 2011, three cases of botulism occurred in a household, due to the consumption of korma sauce. The outbreak was investigated and managed by a multidisciplinary team, which through an epidemiological link and subsequent microbiological confirmation successfully identified the korma sauce as the vehicle of intoxication. Only family members who had tasted or eaten the sauce became ill. The father, who had only tasted the sauce, and the mother who had neither eaten nor tasted it remained well. No other cases have been reported elsewhere to date. Investigations are continuing into the source and cause of the contamination.
3. Health Protection Scotland (HPS). Public Urged to be Aware of Botulism Symptoms. HPS: Glasgow. 11 November 2011. Available from: http://www.hps.scot.nhs.uk/news/SPdetail. aspx?id=435

4. McLauchlin J, Grant KA, Little CL. Food-borne botulism in the United Kingdom. J Public Health. 2006;28(4):337-42.

\section{References}

1. Centers for Disease Control and Prevention (CDC). Botulism in the United States, 1899-1996. In: Handbook for Epidemiologists, Clinicians, and Laboratory Workers, Atlanta, GA. Atlanta: CDC; 1998.

2. Food Standards Agency (FSA). FSA warning on certain jars of Loyd Grossman Korma sauce. FSA: London. 13 November 2011. Available from: http://www.food.gov.uk/news/ newsarchive/2011/nov/botulismwarn 